\title{
Basic Life Values of Prospective Special Education Teachers
}

\author{
1Dr. Maria Sohaib Qureshi* ${ }^{2} D r$. Syeda Samina Tahira \\ 3Dr. Muhammad Irfan Arif
}

1. Assistant Professor, Institute of Special Education, University of the Punjab, Lahore, Punjab, Pakistan

2. Dean, Faculty of Arts and Social Sciences, Govt. College Women University, Faisalabad, Punjab, Pakistan

3. Lecturer, Department of Special Education, University of Education, Lahore, Punjab, Pakistan

\begin{tabular}{|c|c|}
\hline & \\
\hline & \multirow{7}{*}{$\begin{array}{l}\text { Future teachers' preconceived values about how to live their lives and } \\
\text { how that affects the lives of their students were the focus of this study. } \\
\text { Descriptive research was used by the researchers. The study was } \\
\text { carried out by using Morris's Ways to Live Scale. Researchers used } \\
\text { this scale to study prospective special education teachers' gender, } \\
\text { social status, personal relationships, aesthetics and mental approach } \\
\text { using purposive sampling method. Descriptive and inferential stats } \\
\text { were used to analyse the data collected from those who participated } \\
\text { in the study on basic life values of prospective teachers. Results } \\
\text { indicated that being social and sympathetic are the most important } \\
\text { values among prospective special education teachers. It was also } \\
\text { found that male and female prospective special education teachers } \\
\text { living in urban and rural areas had no significant differences in their } \\
\text { basic life values. }\end{array}$} \\
\hline & \\
\hline & \\
\hline & \\
\hline & \\
\hline & \\
\hline & \\
\hline
\end{tabular}

\section{Introduction}

Values represent key aspects of right and wrong or good or bad. Values according to Giddens (2006) are detained by human being about appropriateness, attractiveness or suitability. These parameters vary among humans and are strongly influenced by their culture Davis (2018). Basic values include ethics or character. Values provide commands in life comprising preference, duty, moral obligation, desire, wants, needs, goals, happiness, pleasure, likes and dislike, and much more. Kemmelmeier and Oyserman (2001) discussed that we can say that values are presence of criteria and standards of preference General principles guide our actions and they are known as values. Values are not actually actions in fact they are a guiding code which steam line our actions and our certain behaviours. A list of criteria by which behaviour is judged and consequences called upon are known as values. According to Griffiths and Keirns (2015) sociologists have defined those beliefs and values are the main factors modifying the behaviour of a group or community.

Teaching is a sacred and distinctive profession. Teacher is a very popular personality in society (Adeeb, 2009). Much historical evidence is there according to them education distinguished progress. A nation becomes famous if they give value and worth to their teachers. Teachers made nations winner. Now a day's teaching profession becomes more demanding and more complicated as compared to past eras. Teacher is expected to be a role model. For colleagues, students and family the teacher should show respect and care. The teacher can make changes in students with their vision and rationality. Teacher's intellectual value allows students to be artistic, creative, ideological and different. The personality of the teacher encourages students to reshape their selves and become better 
citizens. So, a teacher should have professional attitude. Socio-economic development of a nation depends on a teacher. It is the teacher who makes changes in students. A teacher is an ambassador in mechanism of exchanging ideas, knowledge as well as values among a society in general and across the globe utilizing the media of conferences, workshops and publications.

The best prospective teachers have values like tolerance, understanding and kindness. So, they can understand the psychology their students and to imagine what the students think and feel and anticipating what they need to learn and grow. A prospective teacher must be trained enough so he can understand the problems of struggling students and prospective teacher should know how to evolve the frustration of fed-up students. And the compassionate teacher will try everything and anything to reach every student. Great teachers know that what can make them different from rest of the teachers.

Value of a Teacher is that he never been discouraged easily and always tries to meet their students' learning goals. A good teacher has quality to face barriers and obstacles while achieving, on short-and long-term goals. Effective teachers accept the challenge of the teaching profession as part of the fulfilment of the global nature of their careers.

A good teacher has value of meeting the expectations of students and community. They use latest teaching techniques, strategies and tactics to fulfil desire student's outcomes. It is also important that teachers are results-oriented and always on the lookout for the latest innovation in teaching. They always try to strengthen and recommitted themselves to their mission as educators.

Empowered teachers like dynamic classroom teaching and do not try to change it. They like to enhance curiosity of individuals and try to use some innovative activities. Effective teachers try to produce a difference in their students' lives by thinking outside the box and being fearless in technical Era. Instead of using old methods of teaching they use new pedagogy. They try to diagnose problems of students and use problem solving skills on an ongoing basis.

Being teacher, the concept of self-fulfilling prophecy plays a huge role because teacher expectations often determined student outcomes. A teacher deals his every student to meet his highest expectations. Being a good teacher self fulfilment is a great value which every teacher should have actually. Humour is a good teacher's approach. A good teacher has good sense of humour. They are warm and never been discouraged by obstacles of the way of fulfilment of their teaching objectives. With a strong, positive and self esteemed attitude they become most favourite teachers they never make students bore and students always demand for such kind of teacher. Such teacher gives a smile to student and tries to give emphasis on lesson delivery. 


\section{Hypothesis}

1) There is no significant mean difference among the basic life values of prospective special education teachers.

2) There is no significant mean difference between the basic life values of male and female prospective special education teachers

3) There is no significant mean difference among the opinions of prospective special education teachers of different ages about basic life values.

4) There is no significant mean difference between the opinions of urban and rural prospective special education teachers about basic life values.

\section{Material and Methods}

\section{Research Design}

Quantitative approach was adopted to explore the basic life skills of prospective teachers. The researchers used descriptive research design employing Morris's Ways to Live Scale to see the teacher education's relation to the life skills of prospective teachers. Charles Morris made WTLS in 1956. Unlike Kernes and Kinner (2005), kaashmeeri (2008) applied this scale to measure life skills of teachers and students in Pakistan. He administered the ways to live scale in Pakistan to assess the conceived values of Pakistani society, which yielded a useful framework. While by using this scale researchers studied the personal and interpersonal approach of prospective teachers regarding their gender, social status, personal relationships, aesthetics, and mental approach.

\section{Sample of the Study}

Population of the study comprised male and female prospective special education teachers living in the Punjab Province. As it was not possible for the researchers to access the total population for the study, purposive sampling technique was used for the study considering it a suitable technique to gather data. Two hundred and eighty prospective teachers were selected as a sample for this study.

\section{Instrument for Data collection}

The researchers used WTLS to measure the basic life values of prospective teachers. The Ways to Live scale WTLS was originally designed from combining three basic components of personality (Morris,1956) expressed in major religious, ethical, and 
philosophical systems in the world. The thirteen ways to live items which were developed on the basis of these personality components are:

Way 1: Participation in social life,

Way 2: Independent and self reliance,

Way 3: Sympathetic and caring for community,

Way 4: moderate in life,

Way 5: cooperative with others,

Way 6: consistent,

Way 7: versatile,

Way 8: delightful/ cheerful,

Way 9: receptive,

Way 10: self control,

Way 11: contemplative,

Way 12: energetic,

Way 13: generous

The WTLS was based on 13 major variables as described above. This was used to identify basic life values comprising personal, social as well as educational matters of prospective special education teachers of Punjab.

Reliability of the scale was found significant Cronbach's Alpha .72. Morris (1956), Kernes and Kinner (2005) and kaashmeeri (2008) used Cronbach Alpha to determine reliability of WTLS.

\section{Data Collection and Analysis}

Researchers collected the data by handing over the questionnaires to the prospective special education teachers and collecting it from them. Out of 350 questionnaires distributed, 284 were received, from which 280 were found completely 
filled by the respondents. Data for study of basic life values of prospective teachers was analysed through descriptive and inferential statistical techniques.

\section{Results and Discussion}

Table 1

Distribution of Respondent by Gender

\begin{tabular}{cc}
\hline Gender & Percentage \\
\hline Male & 10.1 \\
Female & 89.9 \\
\hline
\end{tabular}

The above table shows the distribution of Male and Female respondent. Percentages of Male respondents were 10.1 and percentages of Female respondents were 89.9. The proportion of Female respondents was higher than the proportion of Male respondents. Malik, Qureshi and Bano (2021, p.23) indicates 'Pakistan being a developing nation is building upon the female segment of the population and especially in the field of education'.

Table 2

Age wise Distribution of Respondent

\begin{tabular}{cc}
\hline Ages & Percentage \\
\hline $16-20$ & 1.9 \\
\hline $21-24$ & 50.4 \\
\hline $25 \&$ above & 47.7 \\
\hline
\end{tabular}

The above table shows the $2 \%$ of respondent were $16-20$ years old, $50 \%$ were $21-24$ years old while, $48 \%$ were 25 years old \& above.

Table 3

Distribution of Respondent by Area

\begin{tabular}{cc}
\hline Area & Percentage \\
\hline Urban & 75.2 \\
\hline Rural & 24.8 \\
\hline
\end{tabular}

The above table shows that $75.2 \%$ were respondents from urban area and $24.8 \%$ were respondent from rural area. 
Table 4

Percentage, Mean and SD of Basic life Value

\begin{tabular}{|c|c|c|c|c|c|c|c|c|c|}
\hline \multicolumn{10}{|c|}{ Percentage of basic life values } \\
\hline$\underline{\text { Statements }}$ & $\begin{array}{c}\text { I dislike } \\
\text { it very } \\
\text { Much }\end{array}$ & $\begin{array}{c}\text { I dislike } \\
\text { it quite } \\
\text { a lot }\end{array}$ & $\begin{array}{l}\text { I dislike it } \\
\text { slightly }\end{array}$ & $\begin{array}{c}\text { I am } \\
\text { indiffer } \\
\text { ent to it }\end{array}$ & $\begin{array}{l}\text { I like it } \\
\text { slightly }\end{array}$ & $\begin{array}{c}\text { I like it } \\
\text { quite a } \\
\text { lot }\end{array}$ & $\begin{array}{c}\text { I like } \\
\text { it } \\
\text { very } \\
\text { Much }\end{array}$ & Mean & SD \\
\hline $\begin{array}{l}\text { Participation } \\
\text { in Social Life }\end{array}$ & 17 & 13 & 11 & 22 & 29 & 80 & 86 & 5.39 & 1.807 \\
\hline $\begin{array}{l}\text { Independent/ } \\
\text { Self-Reliance }\end{array}$ & 12 & 15 & 25 & 26 & 39 & 80 & 61 & 5.13 & 1.734 \\
\hline $\begin{array}{c}\text { Sympathetic/ } \\
\text { Caring }\end{array}$ & 15 & 18 & 13 & 31 & 30 & 66 & 85 & 5.25 & 1.845 \\
\hline Moderate & 23 & 17 & 28 & 38 & 55 & 66 & 31 & 4.58 & 1.781 \\
\hline Cooperative & 20 & 13 & 23 & 34 & 60 & 66 & 42 & 4.81 & 1.751 \\
\hline Consistent & 14 & 12 & 19 & 43 & 40 & 79 & 51 & 5.03 & 1.690 \\
\hline Versatile & 9 & 13 & 16 & 35 & 39 & 78 & 68 & 5.28 & 1.638 \\
\hline $\begin{array}{c}\text { Delightful/ } \\
\text { Cheerful }\end{array}$ & 25 & 17 & 25 & 45 & 47 & 63 & 36 & 4.57 & 1.826 \\
\hline Receptive & 14 & 21 & 25 & 38 & 40 & 70 & 50 & 4.86 & 1.782 \\
\hline Self-Control & 12 & 9 & 18 & 40 & 38 & 74 & 67 & 5.22 & 1.667 \\
\hline Contemplative & 20 & 18 & 24 & 35 & 47 & 65 & 49 & 4.79 & 1.832 \\
\hline Energetic & 9 & 17 & 24 & 35 & 47 & 69 & 57 & 5.05 & 1.679 \\
\hline Generous & 16 & 17 & 16 & 29 & 31 & 61 & 88 & 5.24 & 1.872 \\
\hline
\end{tabular}

Table 4 shows that the mean value of participation in social life was 5.39 and standard deviation was 1.807 . Majority of prospective teachers were very much likely to participate in social life. The mean value of self-reliance was 5.13 and standard deviation was 1.734. Majority of prospective teachers liked it quite a lot to be self-reliant in life. The mean value of sympathetic / caring was 5.25 and standard deviation was 1.845. Majority of prospective teachers were much likely to be sympathetic / caring. The mean value of moderate was 4.58 and standard deviation was 1.781 . Nearly half of the prospective teachers disliked it to be moderate. The mean value of cooperative was 4.81 and standard deviation was 1.751. Most of the prospective teachers liked it to be cooperative. The mean value of consistent was 5.03and standard deviation was 1.690. Majority of prospective teachers liked it quite a lot to be consistent. The mean value of versatile was 5.28 and standard deviation was 1.638. Majority of prospective teachers liked it quite a lot to be versatile. The mean value of delightful / cheerful was 4.57 and standard deviation was 1.826. Nearly half of the prospective teachers liked it to be delightful / cheerful. The mean value of receptive was 4.86 and standard deviation was 1.782 . Most of the prospective teachers liked it to be receptive. The mean value of self-control was 5.22 and standard deviation was 1.667. Majority of prospective teachers preferred to have self-control. The mean value of contemplative was 4.79 and standard deviation was 1.832. Nearly half of the prospective teachers were likely to be contemplative. The mean value of energetic was 5.05 and standard deviation was 1.679. Majority of prospective teachers liked it to be energetic. 
The mean value of generous was 5.24 and standard deviation was 1.872 . Majority of prospective teachers were very much likely to be generous.

Table 5

Difference between the Opinions of Prospective Teachers about Basic values of life on Gender Basis

\begin{tabular}{ccccccc}
\hline & $\mathrm{N}$ & Mean & SD & df & T & Sig. \\
\cline { 1 - 3 } Male & 26 & 63.19 & 11.802 & \multirow{2}{*}{256} & \multirow{2}{*}{-.853} & \multirow{2}{*}{395} \\
\hline Female & 232 & 65.42 & 12.708 & & & \\
\hline
\end{tabular}

Table 5 shows that $t$-value $(-.853)$ is not significant at $p \leq 0.05$ level of significance, therefore null hypothesis that "there is no significant mean difference between the opinions of male and female prospective teachers about basic life values" is not accepted.

Table 6

Difference among the Opinions of Prospective Teachers about Basic values of life on Age

\begin{tabular}{|c|c|c|c|c|c|}
\hline \multicolumn{6}{|c|}{ Basis } \\
\hline & Sum of Squares & Df & $\begin{array}{c}\text { Mean } \\
\text { Square }\end{array}$ & $\mathrm{F}$ & Sig. \\
\hline Between Groups & 10.484 & 2 & 5.242 & & \\
\hline Within Groups & 40891.826 & 255 & 160.360 & .033 & .968 \\
\hline Total & 40902.310 & 257 & & & \\
\hline
\end{tabular}

Table 6 shows that F-value (.033) is not significant at $\mathrm{p} \leq 0.05$ level of significance, therefore null hypothesis that "there is no significant mean difference among the opinions of prospective teachers of different ages about basic life values" is accepted.

Table 7

Difference between the Opinions of Prospective Teachers about Basic values of life on Area Basis

\begin{tabular}{ccccccc}
\hline & $\mathrm{N}$ & Mean & SD & Df & T & Sig. \\
\hline Urban & 194 & 65.12 & 12.701 & \multirow{2}{*}{256} & \multirow{2}{*}{-.155} & .771 \\
\cline { 1 - 3 } Rural & 64 & 65.41 & 12.449 & & & \\
\hline
\end{tabular}

Table 7 shows that $t$-value $(-.155)$ is not significant at $\mathrm{p} \leq 0.05$ level of significance, therefore null hypothesis that "there is no significant mean difference between the opinions of Urban and Rural prospective teachers about basic life values" is not accepted.

\section{Discussion}

Teaching profession and social values are interrelated. Versatility in values gives flavour to teacher's teaching style as well as empowers a teacher. The prospective teacher needs to be aware of the dynamics of teaching. Oliver and Reschly (2007) said that many 
factors influence the process of teaching. There are many dynamics within a class as well as in outside environment that influences the teaching learning process. Teachers' perspective way of life is among the factors that are likely to influence student's performance.

Analysis of the data obtained clearly indicate that prospective teachers prefer participation in social life over other ways of life. Being sympathetic, caring generous and self-reliant was also among popular ways of life among perspective teachers. On the other hand, nearly half of the prospective teachers disliked being moderate in life. Same likely, way of life that encourages cooperation was not preferred by nearly half of the teachers. Although, cooperative way of life tends to result in team teaching and other benefits of working together, but it seemed to be lacking in nearly half of the prospective teacher which is quite alarming. Despite the fact that delight reduces stressors in life, being delightful and receptive were also among the less preferred ways of life by nearly half of prospective teachers.

\section{Conclusion}

It was concluded that no significant difference exists between the opinions of male and female prospective special education teachers of different ages about the basic values of life. Likewise, prospective special education teachers living in urban and rural area have no significant difference in their opinions about the basic values of life.

\section{Recommendations}

As a result of our research, we learned that in modern Pakistani society, among prospective special education teachers of Pakistan being social is the most important value. However, more research needs to be done in this area to identify the reasons of such preferences of prospective teachers. Additionally, comparing the life values of teachers living in different provinces of the country might yield more understanding of our teachers. 


\section{References}

Adeeb, M. (2009). Teaching as a profession, Professional Competency Enhancement Program For Teachers. Islamabad: National Academy Of Higher Education (NAHE).

Davis, T. (2018). 39 Core Values and How to Live by Them. Sussex: Psychology Today.

Giddens (2006). Sociology. Cambridge: Polity Press.

Griffiths, H. and Keirns, N. (2015). Introduction to Sociology. Houston, Taxes: OpenStax.

Gulla, A. (2010). Creating Values in Life. Indiana: Author House.

Jimenez, J. C. (2009). The significance of values in an organization. Caracas: Cograff Comunicaciones.

Kemmelmeier, M., \& Oyserman, D. (2001). Gendered Influence of Downward Social Comparisons on Current and Possible Selves. Journal of Social Issues, 57(1), 129-148.

Kernes J. \& Kinnier (2005) "Psychologists Search For The Good Life, Journal of Humanistic Psychology, 45 (1)

Malik, M., Qureshi, M.S. and Bano, H. (2021). Self-Efficacy of Teachers in Special Education. International Journal of Rehabilitation and Special Education, 1 (1), 13-26.

Morris, C. (1956). Varieties of human value. USA: Franklin Classics.

Morris, C., \& Jones, L. V. (1955). Value scales and dimensions. The Journal of Abnormal and Social Psychology, 51(3), 523-535.

Tiempo, A. (2005). Social philosophy: foundations of values education. Manila: Rex Book Store. 